\title{
Motivasi Kerja pada Driver Go-Car Ditinjau dari Psychological Contract dan Person-Organization Fit
}

\author{
Ika Puspitasari $^{1 *}$, Aditya Nanda Priyatama ${ }^{2}$, Selly Astriana $^{1}$ \\ ${ }^{1}$ Program Studi Psikologi, Fakultas Kedokteran, Universitas Sebelas Maret, Surakarta \\ ${ }^{2}$ Program Studi Psikologi, Fakultas Kedokteran, Universitas Sebelas Maret, Surakarta dan \\ Program Doktor, Fakultas Psikologi, Universitas Airlangga, Surabaya \\ *puspitasariika9@gmail.com
}

\begin{abstract}
Human resources is an important factor in the organization. This reason underlied the need to create work motivation in working field. Motivation is influenced by the desire to achieve goals, both individual goals or organization goals. Those can be seen through psychological contract and personorganization fit. The purpose of this study is: 1) to determine the relation of psycological contract and person-organization fit with work motivation on the Go-Car drivers, 2) to determine the relation between psycological contract with work motivation on the Go-Car drivers, 3) to determine the relation between person-organization fit with work motivation on the Go-Car drivers. This study uses a purposive random sampling with sample of 81 Go-Car drivers in Surakarta. The result of this research shows there is a significant positive relation between psychological contract and person-organization fit with work motivation on the Go-Car drivers.
\end{abstract}

Keywords: Psychological Contract, Person-Organization Fit, Work Motivation.

\section{PENDAHULUAN}

Faktor dari sumber daya manusia menjadi elemen yang mendapat perhatian khusus oleh sebuah organisasi, karena tingkat kompetisi yang tinggi memaksa organisasi untuk mempertahankan kelangsungan hidupnya. Alasan tersebut yang kemudian mendasari perlu adanya motivasi sebagai dorongan untuk menciptakan semangat kerja individu dalam sebuah organisasi guna tercapainya tujuan organisasi. Setiap pekerjaan atau kegiatan tertentu membutuhkan motivasi yang tinggi supaya dapat menjalankan pekerjaan serta mampu menciptakan kinerja yang bersemangat, bergairah dan berdedikasi (Nawawi, 2003).
Motivasi seorang individu dalam bekerja dipengaruhi oleh keinginannya dalam mencapai tujuan. Tujuan harus selaras dengan tujuan organisasi supaya kegiatan yang dilakukan individu tidak jauh menyimpang dari kegiatan perusahaan (Darmawan, 2013). Oleh sebab itu, menjadi sebuah hal yang penting untuk menyelaraskan dan menyeimbangkan tujuan dari kedua belah pihak dalam mencapai keberhasilan. Keberhasilan tidak dapat lepas dari hubungan timbal balik yang terjadi antara karyawan dan organisasi (Nasution dan Seniati, 2013). Hubungan tersebut mengakibatkan masing-masing pihak berusaha untuk mengembangkan pandangan dan harapan (ekspektasi) tententu. Harapan dan kewajiban timbal balik antara individu 
dan organisasi inilah yang dikenal sebagai kontrak psikologis (psychological contract) (Tsui, Lin, dan Yu, 2013).

Organisasi menginginkan individu dengan motivasi kerja yang tinggi untuk menjalankan setiap proses atau kegiatan kerja organisasi yang stabil atau bahkan meningkat. Oleh karena itu, organisasi perlu memastikan kesesuaian antara nilai-nilai organisasi dengan nilai-nilai pada individu dalam organisasi tersebut (Astuti, 2010). Pemahaman tentang person-organization fit dapat membantu organisasi dalam memilih dan menentukan individu dengan nilai dan keyakinan yang sesuai dengan perusahaan dengan cara membentuk pengalaman yang dapat memperkuat kesesuaian nilai tersebut. Penelitian tentang person-organization fit memberikan pemahaman tentang pentingnya meningkatkan kesesuaian antara karyawan dan perusahaan, membentuk loyalitas karyawan terhadap perusahaan dan meningkatkan komitmen karyawan, serta meningkatkan outcomes karyawan yang berdampak pada pertumbuhan perusahaan yang strategis dan berkelanjutan (Astuti, 2010).

Salah satu bisnis jasa yang berkembang pesat dalam dunia modern saat ini adalah jasa transportasi online. Go-jek adalah salah satu perusahaan yang bergerak dalam bisnis tersebut (Marati, 2016). Go-jek menyediakan berbagai layanan, diantaranya adalah Go-Car. Go-Car menyediakan layanan antar jemput menggunakan mobil. Semakin banyaknya driver Go-Car merupakan fenomena yang menarik untuk diteliti. Dari hasil wawancara dengan 5 driver Go-Car di Surakarta tahun 2018 terungkap bahwa jumlah driver Go-Car yang semakin meningkat setiap waktu disebabkan karena lingkungan kerja mendukung dan benefit yang didapatkan bagi para driver GoCar itu sendiri.

Di sisi lain, dari wawancara tersebut dijelaskan bahwa driver Go-Car memiliki banyak permasalahan yang kemudian dapat mempengaruhi motivasinya dalam bekerja. Permasalahan seperti jumlah driver Go-Car yang tidak diimbangi dengan banyaknya penumpang, peraturan tentang kuota maksimal 4 orang tiap mobil tidak ditaati oleh penumpang, kemungkinan resiko yang terjadi selama mengemudi ditanggung penuh oleh driver, terdapat beberapa wilayah atau zona tertentu yang tidak memperbolehkan driver Go-Car untuk masuk dan mengambil penumpang, yaitu di stasiun, terminal, bandara, beberapa rumah sakit, mall, hotel dan wilayah lain yang terdapat ojek pangkalan, taksi konvensional maupun becak. Selain itu, permasalahan lainnya adalah banyak pihak yang merasa tersaingi, lalu tidak mendukung adanya Go-Car tersebut. Hal tersebut dibuktikan dengan aksi yang dilakukan oleh pengemudi becak dan ojek pangkalan yang berjumlah ratusan orang dan menggeruduk Balai Kota Solo, Jalan Jenderal Sudirman Nomor 02, Kampung Baru dalam rangka menolak keberadaan transportasi berbasis online untuk beroperasi di Kota Solo. Beroperasinya go-jek termasuk juga $\mathrm{Go}-\mathrm{Car}$ di Solo selama tiga bulan terakhir menyebabkan pendapatan pengemudi becak dan ojek pangkalan menjadi $75 \%$ dari pendapatan semula (Septiyaning, 2016).

Permasalahan tersebut membuat trauma tersendiri bagi para driver Go-Car, yang kemudian dapat berpengaruh pada motivasi kerja sebagai driver Go-Car. Beberapa dari mereka memutuskan untuk tidak aktif bekerja sehingga akunnya ditangguhkan. Di sisi lain, banyak dari driver Go-Car yang masih bekerja keras dan bertahan dalam kondisi tersebut, hal tersebut tidak lepas dari pengaruh internal dan pengaruh eksternal pribadinya. Bahkan, pendapatan driver Go-Car di Solo mayoritas melebihi upah minimum kota (UMK) yaitu sebesar Rp1.534.985 berlaku per 1 Januari 2017 yang ditetapkan melalui SK No. 560/50 Tahun 2016 (Tribun Solo, 2016) atau jauh di atas rata-rata pendapatan driver go-jek nasional (Anggriawan, 2017). Oleh karena itu, berdasar latar belakang di atas, untuk menggali lebih jauh apa mengenai motivasi kerja driver gocar maka peneliti tertarik melakukan penelitian yang berjudul "Hubungan antara Psychological Contract 
dan Person-Organizational Fit dengan Motivasi Kerja pada Driver Go-Car di Surakarta".

\section{Psychological Contract dan Person- Organization Fit dengan Motivasi Kerja}

Robbins (2006) mendefinisikan

motivasi kerja adalah proses yang menghasilkan arah, intensitas dan ketekunan yang berhubungan dengan tujuan organisasi sebagai bentuk cerminan minat pada perilaku kerja. Sejalan dengan hal tersebut, Martoyo (2007) mendefinisikan motivasi kerja merupakan suatu hal yang menyebabkan adanya dorongan atau semangat kerja. Terdapat berbagai faktor yang mempengaruhi motivasi kerja, baik faktor internal maupun faktor eksternal dari individu. Hasil penelitian yang dilakukan oleh Cahyo (2015) pada karyawan di sebuah perusahaan didapatikan hasil yang signifikan bahwa salah satu hal yang mempengaruhi motivasi kerja adalah kontrak psikologis (psychological contract). Kotter (dalam Conway dan Briner, 2005) mendefinisikan psychological contract sebagai kontrak yang sifatnya implisit antara individu dan organisasi yang spesifik pada harapan masing-masing dalam hubungan kerja. Semakin tinggi kontrak psikologis yang dimiliki karyawan maka semakin tinggi pula motivasi kerja karyawan tersebut, begitu pula sebaliknya. Hasil penelitian tersebut sesuai dengan kesimpulan Darmawan (2013) bahwa adanya kontrak psikologis yang wajar, dapat memberi pemahaman akan pemenuhan kebutuhan karyawan yang berdampak pada dorongan karyawan untuk termotivasi dalam bekerja.

Selain kontrak psikologis, juga terdapat satu hal yang perlu diperhatikan oleh organisasi untuk memastikan kesesuaian antara nilai-nilai organisasi dengan nilai-nilai individu dalam organisasi tersebut (Astuti, 2010). Kesesuaian antara nilai individu dan nilai organisasi yang menekankan sejauh mana karakteristik serupa dalam memenuhi kebutuhan masingmasing disebut sebagai person-organization fit (Sekiguchi, 2004). Penelitian yang dilakukan oleh Sugianto, Thoyib dan Noermijati (2012) didapatkan kesimpulan bahwa person-organization fit berpengaruh secara signifikan pada motivasi kerja, komitmen karyawan dan kepuasan kerja. Oleh karena itu, person-organization fit yang tinggi akan diimbangi dengan motivasi kerja, kepuasan kerja dan komitmen karyawan yang tinggi pula, begitu pula sebaliknya. Person-organization fit mengarah pada perasaan tenang dan nyaman seorang individu dalam bekerja sehingga memiliki dampak positif pada kontribusinya di organisasi (Guntur, 2012). Jika kebutuhan karyawan dipenuhi oleh perusahaan, maka akan terbentuk persepsi bahwa ia diperhatikan dan akan berpengaruh pada motivasi atau semangat dalam bekerja. Selama motivasi tersebut kuat, semakin besar pula peluang karyawan untuk lebih konsisten pada tujuan kerja.

\section{Hipotesis}

$\mathrm{H}_{1}$ : Terdapat hubungan antara psychological contract dan personorganization fit dengan motivasi kerja pada driver Go-Car di Surakarta

$\mathrm{H}_{2}$ : Terdapat hubungan antara psychological contract dengan motivasi kerja pada driver Go-Car di Surakarta

$\mathrm{H}_{3}$ : Terdapat hubungan antara personorganization fit dengan motivasi kerja pada driver Go-Car di Surakarta.

\section{METODE}

Penelitian ini merupakan penelitian korelasional antara motivasi kerja sebagai variabel terikat dan psyhological contract serta person-organization fit sebagai variabel bebas. Motivasi kerja adalah proses psikologis berupa dorongan yang membangkitkan, mengelola, mempertahankan, menyalurkan dan menentukan arah tingkah laku yang disertai dengan semangat bekerja dalam rangka mencapai tujuan untuk memenuhi kebutuhan. Psychological contract (kontrak psikologis) adalah harapan timbal balik antara individu dan organisasi sebagai bentuk kontribusi dan imbalan atas 
kontribusi tersebut secara tidak tertulis dan bersifat implisit dari sudut pandang individu tersebut. Person-organization fit didefinisikan sebagai kecocokan atau kesesuaian nilai antara individu dan organisasi yang terjadi ketika setidaknya satu pihak menyediakan kebutuhan pihak lain, atau ketika keduanya memiliki karakteristik fundamental yang serupa. Populasi pada penelitian ini yaitu seluruh driver Go-Car di PT Jayanagiri Surakarta yang berjumlah 411 orang. Sampel pada penelitian ini yaitu 81 driver Go-Car yang dihitung dengan menggunakan pendekatan statistik Issac dan Michael dalam Sugiyono (2014) dengan teknik pengambilan sampel dalam penelitian ini yaitu purposive random sampling.

Instrumen yang digunakan dalam penelitian ini adalah modifikasi dari skala likert. Skala motivasi kerja oleh peneliti berdasarkan aspek-aspek yang dikemukakan oleh Anoraga (2009) terdiri dari 36 item. Skala psyhological contract dimodifikasi dari instrumen penelitian yang dikembangkan oleh Millward dan Hopkins (1998) sesuai dengan dimensi yang dirumuskan oleh Rousseau dan Schalk (2000) terdiri dari 16 item. Skala personorganization fit dimodifikasi berdasarkan aspek-aspek yang dikemukakan oleh Kristof (1996) terdiri dari 26 item.

Tahapan pertama dalam penelitian ini adalah uji instrumen yaitu dengan melakukan uji validitas dan reliabilitas. Pada skala motivasi kerja didapat 22 item valid dengan koefisien reliabilitas alpha sebesar 0,900. Pada skala psychological contract, uji validitas dan reliabilitas menghasilkan 15 item valid koefisien reliabilitas alpha sebesar 0,901, sementara pada skala personorganization fit didapat 20 item valid dengan koefisien reliabilitas alpha sebesar 0,900. Berdasarkan uji validitas dan reliabilitas, data yang didapat dari ketiga instrumen memenuhi persyaratan kehandalan alat ukur.

Selanjutnya metode analisis data yang digunakan adalah analisis regresi berganda. Terdapat uji asumsi dasar sebagai syarat dalam teknik analisis data yaitu uji normalitas yang mengacu pada nilai
Kolmogorov-Smirnov $>0,05$ dan uji linearitas yang mengacu pada signifikansi<0,05. Selain itu, terdapat beberapa uji asumsi klasik yaitu uji multikolinearitas, uji heteroskedastisitas dan uji autokorelasi. Seluruh perhitungan dilakukan dengan bantuan program Statistical Product and Service Solution (SPSS) versi 22.0 for Windows.

\section{HASIL DAN PEMBAHASAN}

Hasil uji normalitas yang mengacu pada nilai Kolmogorov-Smirnov menghasilkan nilai Asymp. Sig (2-tailed) sebesar 0,200 sehingga data penelitian tergolong berdistribusi normal. Sementara untuk uji linearitas variabel psychological contract dengan motivasi kerja dan variabel person-organization fit dengan motivasi kerja diperoleh nilai linearity sebesar 0,000 $(\mathrm{p}<0,05)$ sehingga terdapat hubungan yang linear antara variabel-variabel tersebut.

Berikutnya adalah melakukan uji asumsi klasik. Uji multikolinearitas didapat dari nilai Tolerance sebesar $0,353(\mathrm{p}>0,10)$ dan nilai VIP sebesar 2,830 $(\mathrm{p}<10)$ sehingga dapat dikatakan bahwa pada penelitian ini tidak ditemukan adanya masalah multikolinearitas. Uji heteroskedastisitas didapat titik-titik dalam diagram scatterplot membentuk pola yang tidak teratur. Titiktitik tersebut menyebar di bawah dan di atas angka 0 pada sumbu $Y$ sehingga pada penelitian ini dikatakan tidak terjadi masalah heteroskedastisitas. Selanjutnya untuk uji autokorelasi diperoleh dengan malakukan perhitungan $\mathrm{D}-\mathrm{W}$ yang terletak di antara dU dan 4-dU yaitu $1,6898<2,0280<2,4120$ sehingga dapat dikatakan bahwa pada model regresi penelitian ini tidak memiliki masalah autokorelasi.

Setelah uji asumsi terpenuhi, dilakukan analisis regresi linier berganda dan pengujian hipotesis. 
Tabel 1. Hasil Uji F

\begin{tabular}{lll}
\hline & Nilai & Syarat \\
\hline Sig. & 0,000 & $\mathrm{p}<0,05$ \\
\hline $\mathrm{F}_{\text {hitung }}$ & 134,361 & $\mathrm{~F}_{\text {hitung }}>\mathrm{F}_{\text {tabel }}(3,11)$ \\
\hline $\mathrm{R}$ & 0,880 & $\begin{array}{l}\text { Interval koefisien korelasi } \\
0,800-1,000=\text { sangat kuat }\end{array}$ \\
\hline $\mathrm{R}^{2}$ & 0,775 &
\end{tabular}

Sumber : Statistical Product and Service Solution (SPSS) versi 22.0 (2018)

Hasil pada tabel 1 menunjukkan nilai koefisien korelasi ganda (R) 0,880 dengan nilai koefisien determinasi $\left(R^{2}\right)$ sebesar 0,775 atau $77,5 \%$. Hasil $R^{2}$ ini menunjukkan sumbangan berpengaruh yang diberikan variabel psychological contract dan personorganization fit terhadap motivasi kerja adalah sebesar $77,5 \%$ dan sisanya yaitu sebesar 22,5\% dipengaruhi oleh faktor lain yang tidak diteliti dalam penelitian ini. Nilai pada koefisien korelasi ganda (R) yaitu sebesar 0,880 yang menunjukkan bahwa terjadi hubungan yang sangat kuat antara psychological contract dan personorganization fit dengan motivasi kerja pada driver Go-Car di Surakarta. Berdasar uji F, menunjukkan nilai signifikansi $<0,05$ sehingga dapat dikatakan bahwa hipotesis pertama dalam penelitian ini diterima.

Hasil Uji $F$ tersebut menunjukkan bahwa psychological contract dan personorganization fit secara bersamaan dapat berpengaruh pada motivasi kerja. Individu dengan harapan dan ekspektasi yang tinggi terhadap perusahaan, juga hubungan timbal balik yang sesuai antara individu dan perusahaan dalam hal ini adalah kontribusi dan kompensasi, maka akan berdampak pada tingginya tingkat motivasi individu dalam bekerja.

Tabel 2. Hasil Uji Korelasi Parsial Psychological Contract dengan Motivasi Kerja

\begin{tabular}{|c|c|c|c|c|}
\hline \multicolumn{3}{|c|}{ Control Variables } & \multirow{2}{*}{$\frac{\mathrm{MK}}{1,000}$} & \multirow{2}{*}{$\begin{array}{l}\text { PC } \\
547\end{array}$} \\
\hline POF & MK & Correlation & & \\
\hline & & $\begin{array}{l}\text { Significance } \\
\text { (2-tailed) }\end{array}$ & &, 000 \\
\hline & & Df & 0 & 78 \\
\hline & $\mathrm{PC}$ & Correlation & ,547 & 1,000 \\
\hline
\end{tabular}

\begin{tabular}{crr}
\hline Control Variables & \multicolumn{1}{c}{ MK } & \multicolumn{1}{c}{ PC } \\
\hline Significance &, 000 &. \\
(2-tailed) & 78 & 0 \\
Df & 78
\end{tabular}

a. Cells contain zero-order (Pearson) correlations.

Sumber : Statistical Product and Service Solution (SPSS) versi 22.0 (2018)

Uji korelasi parsial pada tabel 2 antara variabel psychological contract dan motivasi kerja.menghasilkan nilai signifikansi 0,000, sehingga dapat diartikan bahwa psychological contract memiliki pengaruh terhadap motivasi kerja pada driver Go-Car di Surakarta. Sedangkan nilai korelasi antar kedua variabel tersebut adalah sebesar 0,547. Hal tersebut menunjukkan bahwa korelasi antara psychological contract dan motivasi kerja berada pada tingkat yang sedang, Oleh karena itu, dapat disimpulkan bahwa hipotesis kedua dalam penelitian ini diterima.

Tabel 3. Hasil Uji Korelasi Parsial PersonOrganization Fit dengan Motivasi Kerja

\begin{tabular}{|c|c|c|c|c|}
\hline \multicolumn{3}{|c|}{ Control Variables } & MK & POF \\
\hline \multirow[t]{6}{*}{$\mathrm{PC}$} & MK & Correlation & 1,000 & ,452 \\
\hline & & $\begin{array}{l}\text { Significance } \\
\text { (2-tailed) }\end{array}$ & . &, 000 \\
\hline & & Df & 0 & 78 \\
\hline & POF & Correlation & ,452 & 1,000 \\
\hline & & $\begin{array}{l}\text { Significance } \\
\text { (2-tailed) }\end{array}$ & ,000 & \\
\hline & & Df & 78 & 0 \\
\hline
\end{tabular}

a. Cells contain zero-order (Pearson) correlations.

Sumber : Statistical Product and Service Solution (SPSS) versi 22.0 (2018)

Uji korelasi parsial pada tabel 3 menghasilkan nilai signifikansi 0,000 pada korelasi parsial antara variabel personorganization fit dengan motivasi kerja, sehingga dapat diartikan bahwa personorganization fit memiliki pengaruh pada motivasi kerja pada driver Go-Car di Surakarta Sedangkan nlai korelasi antar keduanya adalah sebesar 0,452 . Hal tersebut menunjukkan bahwa korelasi antara personorganization fit dan motivasi kerja berada pada tingkatan sedang. Oleh sebab itu, dapat 
dikatakan bahwa hipotesis ketiga dalam penelitian ini diterima.

Selanjutnya, gambaran umum data hasil penelitian dijelaskan dalam kategorisasi berdasarkan analisis deskriptif data empirik yang disajikan pada tabel 4 berikut.

Tabel 4. Kriteria dan Kategorisasi Responden Penelitian

\begin{tabular}{ccccc}
\hline Var & Kategori & Norma & $\mathrm{N}$ & $\%$ \\
\hline \multirow{3}{*}{ MK } & Rendah & $22 \leqq \mathrm{X}<44$ & 4 & 4,94 \\
& Sedang & $44 \leqq \mathrm{X}<66$ & 22 & 27,16 \\
& Tinggi & $66 \leqq \mathrm{X} \leqq 88$ & 55 & 67,90 \\
\hline \multirow{3}{*}{$P C$} & Rendah & $15 \leqq \mathrm{X}<30$ & 3 & 3,70 \\
& Sedang & $30 \leqq \mathrm{X}<45$ & 12 & 14,81 \\
& Tinggi & $45 \leqq \mathrm{X} \leqq 60$ & 66 & 81,48 \\
\hline \multirow{3}{*}{ POF } & Rendah & $20 \leqq \mathrm{X}<40$ & 4 & 4,94 \\
& Sedang & $40 \leqq \mathrm{X}<60$ & 13 & 16,05 \\
& Tinggi & $60 \leqq \mathrm{X} \leqq 80$ & 64 & 79,01
\end{tabular}

Sumber : Kriteria dan Kategorisasi Responden Penelitian

1. Priyatno (2012)

2. Azwar (2012)

Secara keseluruhan pada tabel 4 kategorisasi pada variabel motivasi kerja, psychological contract dan personorganization fit pada driver Go-Car di Surakarta berada pada kategori yang tinggi. Selanjutnya adalah gambaran umum responden penelitian digolongkan berdasarkan status perkawinan. Kategorisasi responden penelitian pada skala motivasi kerja berdasarkan status perkawinan disajikan pada tabel 5 dan hasil analisis independent $t$-test pada tabel 6 .

Tabel 5. Kategorisasi Responden Penelitian pada Variabel Motivasi Kerja Berdasarkan Status Perkawinan

\begin{tabular}{ccccc}
\hline Status & Kategori & Norma & $\mathrm{N}$ & $\%$ \\
\hline \multirow{2}{*}{$\mathrm{M}$} & Rendah & $22 \leqq \mathrm{X}<44$ & 2 & 5,71 \\
$(\mathrm{~N}=35)$ & Sedang & $44 \leqq \mathrm{X}<66$ & 5 & 14,28 \\
& Tinggi & $66 \leqq \mathrm{X} \leqq 88$ & 28 & 80 \\
\hline \multirow{2}{*}{$\mathrm{L}$} & Rendah & $22 \leqq \mathrm{X}<44$ & 2 & 4,35 \\
$(\mathrm{~N}=46)$ & Sedang & $44 \leqq \mathrm{X}<66$ & 17 & 36,96 \\
& Tinggi & $66 \leqq \mathrm{X} \leqq 88$ & 27 & 58,69
\end{tabular}

Sumber : Kategorisasi Responden Penelitian pada Variabel Motivasi Kerja Berdasarkan Status Perkawinan

1. Azwar (2012)
Tabel 6. Hasil Analisis Independent T-test

\begin{tabular}{|c|c|c|c|c|c|c|c|}
\hline & & \multicolumn{2}{|c|}{$\begin{array}{l}\text { Levene's } \\
\text { Test for } \\
\text { Equality of } \\
\text { Variances }\end{array}$} & \multicolumn{4}{|c|}{ t-test for Equality of Means } \\
\hline & & $\mathrm{F}$ & Sig. & $\mathrm{T}$ & Df & $\begin{array}{c}\text { Sig. } \\
(2- \\
\text { tailed })\end{array}$ & $\begin{array}{l}\text { Mean } \\
\text { Differen } \\
\text { ce }\end{array}$ \\
\hline \multirow[t]{2}{*}{ MK } & $\begin{array}{l}\text { Equal } \\
\text { variances } \\
\text { assumed }\end{array}$ & ,013 & ,910 & 1,844 & 79 & ,069 & 4,047 \\
\hline & $\begin{array}{l}\text { Equal } \\
\text { variances } \\
\text { not } \\
\text { assumed }\end{array}$ & & & 1,804 & 66,598 & ,076 & 4,047 \\
\hline
\end{tabular}

Sumber : Statistical Product and Service Solution (SPSS) versi 22.0 (2018)

Hasil uji independent t-test memperlihatkan bahwa nilai signifikansi (Sig. 2-tailed) sebesar 0,69 ( $p$ value $>0,05$ ). Berdasarkan nilai signifikansi tersebut, maka dapat dikatakan bahwa tidak terdapat hubungan yang signifikan pada variabel motivasi kerja yang ditinjau dari status perkawinan yaitu menikah dan lajang pada driver Go-Car di Surakarta. Kesimpulan tersebut dikonfirmasi oleh penelitian yang dilakukan oleh Cahyani, Wahyuni dan Kurniawan (2016) yang menyebutkan bahwa tidak terdapat hubungan yang positif dan signifikan antara status perkawinan dengan motivasi kerja pada perawat di Rumah Sakit Jiwa.

Secara umum, dapat dikatakan bahwa penelitian ini mampu menjawab ketiga hipotesis penelitian. Psychological contract dan person-organization fit secara bersamaan dapat berpengaruh pada motivasi kerja. Dimana semakin tinggi yang tinggi psychological contract dan personorganization fit akan menyebabkan semakin tinggi pula motivasi kerja. Individu dengan harapan dan ekspektasi yang tinggi terhadap perusahaan, juga hubungan timbal balik yang sesuai antara individu dan perusahaan dalam hal ini adalah kontribusi dan kompensasi, maka akan berdampak pada tingginya tingkat motivasi individu dalam bekerja. 


\section{Kesimpul}

Hasil penelitian menunjukkan bahwa: 1) terdapat hubungan signifikan antara psychological contract dan personorganization fit dengan motivasi kerja pada driver Go-Car di Surakarta, 2) terdapat hubungan signifikan antara psychological contract dengan motivasi kerja pada driver Go-Car di Surakarta, 3) terdapat hubungan yang signifikan antara person-organization fit dengan motivasi kerja pada driver Go-Car di Surakarta.

Hasil analisa juga menunjukkan variabel psychological contract memberikan pengaruh yang lebih besar pada motivasi kerja jika dibandingkan dengan variabel person-organization fit.

\section{DAFTAR PUSTAKA}

Anggriawan, S. (2017, Mei). Pendapatan Driver GO-JEK Solo Lampaui Pendapatan Rata-rata Driver Nasional. Solopos. Retrieved from http://www.solopos.com.

Anoraga, P. (2009). Manajemen Bisnis. Semarang: PT Rineka Cipta.

Astuti, S. D. (2010). Model PersonOrganization Fit (P-O Fit Model) terhadap Kepuasan Kerja, Komitmen Organisasional dan Kinerja Karyawan. Jurnal Bisnis dan Ekonomi, 17(1), 4360.

Azwar, S. (2012). Sikap Manusia: Teori dan Pengukurannya. Yogyakarta: Pustaka Pelajar.

Cahyo, A. D. (2015). Kontrak Psikologis dan Motivasi Kerja Karyawan PT Bahtera Bersaudara Krian. Jurnal Psikologi, 3(1), 75-81.

Cahyani, I. D., Wahyuni, I., \& Kurniawan, B. (2016). Faktor-faktor yang Berhubungan dengan Motivasi Kerja pada Perawat Rumah Sakit Jiwa (Studi pada Bangsal Kelas III RSJD Dr. Amino Gondohutomo Provinsi Jawa Tengah). Jurnal Kesehatan Masyarakat, 4(2), 7685.

Conway, N., \& Briner, R. B. (2005). Understanding Psychological Contract at Work; a Critical Evaluation of Theory and Research. Oxford: Oxford University Press.

Darmawan, D. (2013). Prinsip-prinsip Perilaku Organisasi. Surabaya: Pena Semesta.

Guntur, W. (2012). Pengaruh PersonOrganization Fit, Kepuasan Kerja dan Komitmen Organisasi terhadap Kinerja Perawat. Management Analysis Journal, 1(1), 1-7.

Kristof, A. L. (1996). Person Organization Fit; An Integrative Review of Its Conceptualization, Measurement and Implication. Journal Personel of Psychology, 49(1), 1-49.

Marati, N. C. (2016). Pengaruh Kualitas Layanan dan Harga terhadap Kepuasan Pelanggan Jasa Transportasi Ojek Online (Studi pada Konsumen Gojek di Surabaya). Jurnal Pendidikan Tata Niaga, 3(3), 1-12.

Martoyo, S. (2007). Perilaku Organisasi; Edisi 2. Jakarta: Salemba Empat.

Nasution, F. L. D., \& Seniati, A. L. C. (2013). Pengaruh Kontrak Psikologis terhadap Komitmen Organisasi pada Tenaga Kerja Outsourcing di Perusahaan Penyedia Jasa Outsourcing, 1-22.

Nawawi, H. (2003). Manajemen Strategik Organisasi Non Profit Bidang Pemerintahan. Yogyakarta: Gadjah Mada University Press.

Priyatno, D. (2012). Cara Kilat Belajar Analisis Data dengan SPSS. Edisi Kesatu. Yogyakarta: Andi.

Robbins, S. P. (2006). Perilaku Organisasi; Edisi Lengkap. Jakarta: PT Indeks Kelompok Gramedia.

Rousseau, D. M., \& Schalk, R. (2000). Psychological Contracts in Employment: Cross-national Perspectives. Newbury Park, CA: Sage In Press.

Sekiguchi, T. (2004). Person Organization Fit and Person Job Fit in Employee Selection. A Review of the Literature, 56(6), 179-196.

Septiyaning, I. (2016, Desember). Ratusan Tukang Becak dan Ojek Pangkalan Demo Tolak Ojek Online di Solo. 
Solopos. $\quad$ Retrieved from http://www.solopos.com.

Sugianto, S. K., Thoyib A., \& Noermijati. (2012). Pengaruh Person-Organization Fit (P-O Fit), Motivasi Kerja dan Kepuasan Kerja terhadap Komitmen Pegawai (pada Pegawai UB Hotel, Malang). Jurnal Aplikasi Manajemen, $10(2), 229-238$.

Sugiyono. (2014). Metode Penelitian Pendidikan Pendekatan Kuantitatif, Kualitatif, dan R\&D. Bandung: Alfabeta.

Tsui, P. L., Lin, Y., \& Yu, T. (2013). The Influence of Psychological Contract and Organizational Commitment on Hospitality Employee Performance. Social Behavior and Personality. 41(3), 443-452. 